\title{
COMPARING THE KINDERGARTEN CURRICULUM FRAMEWORK OF THE PHILIPPINES AND MALAYSIA
}

\author{
Leticia N. Aquino1, Nordin Mamat', Mazlina Che Mustafa ${ }^{3}$ \\ aquino.ln@pnu.edu.ph ${ }^{1}$, nordin@fppm.upsi.edu.my ${ }^{2}$, mazlina.cm@fppm.upsi.edu.my ${ }^{3}$ \\ Philippine Normal University, North Luzon, Philippines ${ }^{1}$, Sultan Idris Education University
}

\begin{abstract}
The Philippines and Malaysia are members of ASEAN who respond to the challenge of EFA goals and Work Plan on Education 2016-2020, particularly on Sustainable Development Goal (SDG) target 4.2: "By 2030 ensure that all girls and boys have access to quality early childhood development, care and pre-primary education so that they are ready for primary education." In response to this, the Philippines Department of Education (DepEd) through its K-12 Program, has made Kindergarten Education mandatory in the Basic Education Curriculum which paves way to the formulation of the new Kindergarten Curriculum Framework. On the other hand, the Ministry of Education (MOE) in Malaysia has also come up with its revised Kurikulum Standard Prasekolah Kebangsaan or National Preschool Standard Curriculum (NPSC) to meet new policy demands under the 2013-2025 Malaysia Education Development Plan (PPPM) and current needs. This paper takes cognizance on the role of curriculum as one of the significant components of the Kinder program as it compares the National Curriculum Standards of the two countries for the Kindergarten program with the aim to look into its developmentally appropriate curriculum features for better child growth, learning and development. Using Documentary analysis and NVivo, themes are identified and categorized from the interview and FGD of the kindergarten teachers, parents and principals from the selected government kindergarten school-respondents. Consequently, this study reveals some points of similarity and difference on kindergarten learning domains, teaching-learning processes, and issues in the current implementation of the Kindergarten program. The paper recommends that action be taken by the different program stakeholders in order to address quality delivery of the Kindergarten program.
\end{abstract}

Keywords: Early childhood education. Kindergarten Curriculum. Learning domains. Teaching approaches. Teaching-learning process

\section{INTRODUCTION}

Philippines and Malaysia believe in the significance of Early Childhood Education (ECE) as a strong arm to eradicate poverty, achieve economic stability and aspire for good and quality life for their people (k-12 Toolkit, 2012). ECE programs made notable gains in school readiness during the year with increased knowledge and skills in pre-academic/cognitive, receptive vocabulary, and social/emotional domains (Goldstein 2013, Taleb 2013, Fess 2014, Haug 2013).

On July 19-21, 2016, UNESCO, UNICEF, the Asia-Pacific Regional Network for Early Childhood (ARNEC) and the Malaysian Ministry of Education organized the Asia-Pacific Regional Policy Forum on ECCE which took place in Putrajaya, Malaysia. In the forum, highlevel policy-makers from throughout Asia-Pacific have committed to advancing equitable, 
quality early childhood care and education (ECCE) in the region with the adoption of the Putrajaya Declaration. It includes an action agenda to guide countries as they seek to achieve Sustainable Development Goal target 4.2: "By 2030 ensure that all girls and boys have access to quality early childhood development, care and pre-primary education so that they are ready for primary education." (ASEAN Integration, 2015).

In response to this global goal, the Philippine educational system has undergone a significant metamorphosis when Republic Act No. 10533 was signed into law known as Enhanced Basic Education Act of 2013. It is an act enhancing the Philippine Basic Education System by strengthening its curriculum and increasing the number of years for basic education. It encompasses at least one (1) year of kindergarten education, six (6) years of elementary education, and six (6) years of secondary education, in that sequence. Secondary education includes four (4) years of junior high school and two (2) years of senior high school education.

The Kindergarten program has been intensified by the RA 10157 in 2012 known as the "Kindergarten Education Act". It mandates kindergarten as the first stage of compulsory and mandatory formal education. The kindergarten education program will be comprised of one year of preschool education for children aged five ( $\mathrm{K}$ to 12 Curriculum Guide - Kindergarten 2012).

The Republic Acts bring another milestone in the history of the Philippine educational system for it can be recalled that before the implementation of the $\mathrm{K}$ to 12 Basic Education Curriculum, the Philippines was the last in Southeast Asia and only one of three (3) countries in the world with a 10-year basic education (SEAMEO INNOTECH 2012).

The table below depicts the regional comparison of the structure, content, organization, and adequacy of basic education in the Philippines shows that the Philippines has the shortest cycle of education as shown below: 
Table 1. Regional Comparison of the Structure, Content, Organization, and Adequacy of Basic Education

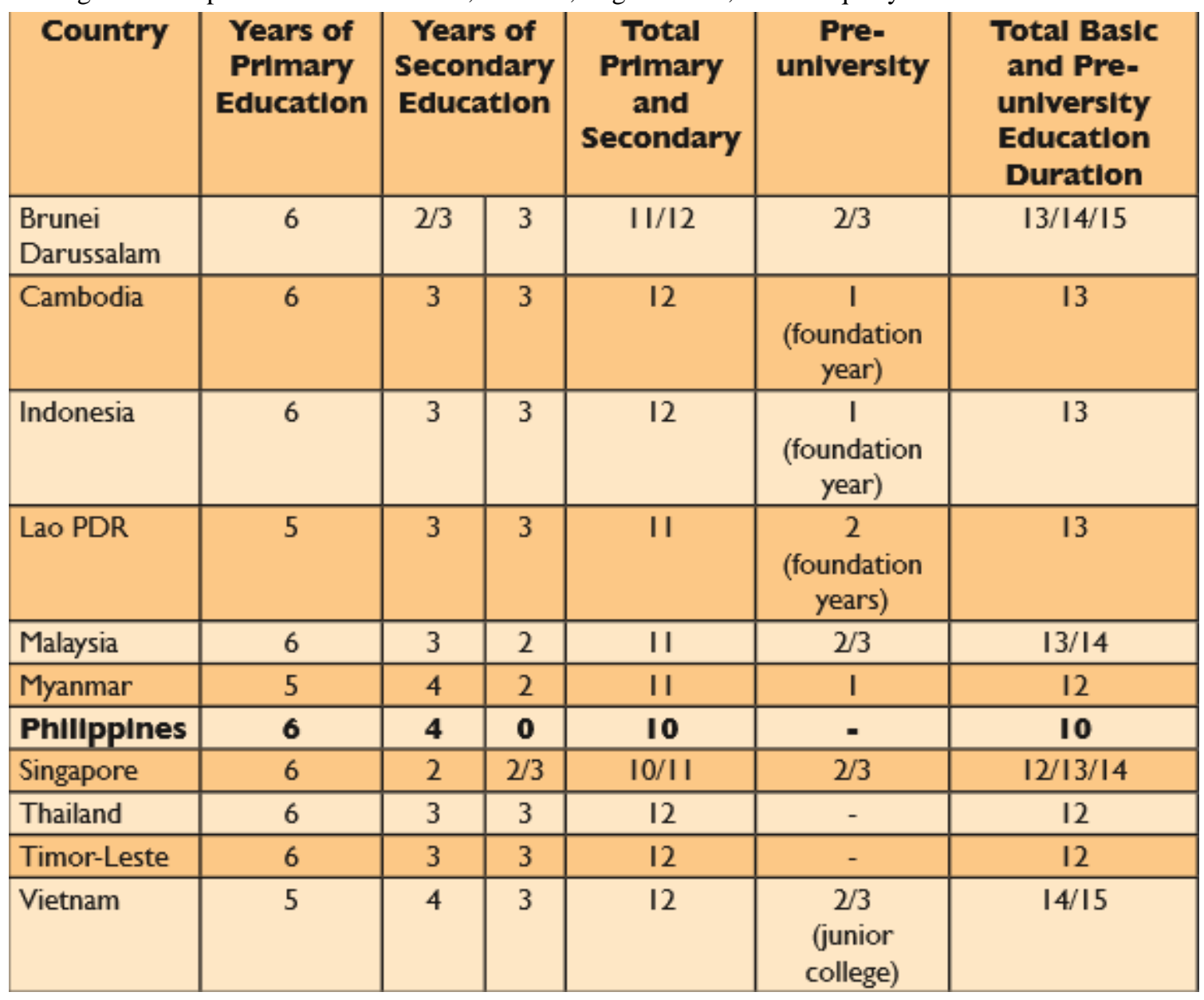

Source: SEAMEO INNOTECH, 2012. K to 12 in Southeast Asia: Regional Comparison of the Structure, Content, Organization, and Adequacy of Basic Education, Philippines

Malaysia on the other hand, has also strengthened its preschool program through Education Act 1996 (Act 550). The Act has permitted the setting up of preschools formally in government schools. With Act 550, the Ministry of Education (MOE) started to build and open preschool classes at an average of 796 classes per year (from 2002 to 2007). Preschool was formally introduced as a part of the national education system under the Education Act 1996. It is important to note however, that the preschool education in Malaysia is not mandatory for entrance to Standard 1.

With these laws introduced respectively by the Malaysia and Philippine government, the Kindergarten curriculum has been given much attention and has been put into place to address global demands for early children education of young children.

In the Philippines, a new curriculum guide for kindergarten program has been crafted in 2011 and a revision was made in 2013. On the other hand, Malaysia has also revised their curriculum for 2017. 
This study compares the kindergarten curriculum of Malaysia and Philippines. It sought to answer the following questions:

1. How are Philippines and Malaysia similar or different in their kindergarten curriculum learning domains?

2. How does the curriculum framework affect the teachers' teaching and learning process?

3. What are the issues raised by the school heads, teachers and parents regarding the implementation of the National Kindergarten curriculum standards in both countries?

\section{METHODOLOGY}

This is a qualitative study involving a purposive sample of 8 kinder teachers, 8 principals and 8 parents of the kindergarten program from 8 schools to combine both Malaysia and Philippines. The data was collected using documentary analysis, interview and focus group discussion. The focus group discussion and interview protocols were guided by questions to know the perceptions of the respondents pertaining to the kindergarten curriculum. Responses and discussions from the respondents were analyzed using NVivo and emerging themes were identified: 1) The government mandates the use of National kindergarten curriculum; 2) Kindergarten education is Mother-tongued instruction based; 3) The Kindergarten curriculum is child centered employing the integrative, thematic, collaborative, inquiry-based, reflective and constructive teaching; 4) Kindergarten education is contextualized; 5) Kindergarten

curriculum is play-based; and 6) Kindergarten curriculum involves parents participation for successful development of the children.

In gathering the data, I sought permission, through a formal letter, from the Department of Education (DepEd) Central Office, to conduct FGD and interview with the school principals, teachers and parents in the Philippine setting and from the Ministry of Education (MOE) in Malaysian setting. I personally conducted the interview and Focus Group Discussion (FGD) with the head masters or principals, teachers, and parents. The interviews with them are conducted in the school and outside the school.

I also asked for permission to dig government or public documents pertaining to the kindergarten program on variables I needed such as the Kindergarten National Standard Curriculum used in both countries. NVivo was used to code and identify themes and subthemes in my interview, FGD and documentary analysis.

\section{RESULTS}

A documentary analysis was used to answer question number 1. The Kindergarten Curriculum Guide of the Philippines was compared with Malaysia's "The National Pre-School Standard Curriculum (KSPK)". 
Question Number 1. How are Philippines and Malaysia similar or different in their kindergarten curriculum learning domains?

The Kindergarten Learning Domains

Philippine Setting

The Philippine Kindergarten Curriculum Standard was first implemented in 2012 but underwent revision in 2013. It contains the following domains: 1) Physical Health and Motor Development; 2) Socio-Emotional Development; 3) Values Education; 4) Language, Literacy and Communication; 5) Mathematics; 6) Social Development; and 7) Understanding of the Physical and Natural Environment.

Table 2. The Learning Domains of Philippine Kindergarten Program

\begin{tabular}{|c|c|}
\hline 7 Domains of Learning & Descriptions \\
\hline $\begin{array}{l}\text { 1. Values Education } \\
\text { Asal) }\end{array}$ & $\begin{array}{l}\text { Children are expected to show positive self- } \\
\text { concept, respect and concern for self and } \\
\text { others, how to follow and behave } \\
\text { appropriately in various situations and } \\
\text { places, manifest love of God, country and } \\
\text { fellowmen. }\end{array}$ \\
\hline $\begin{array}{l}\text { 2. Physical Health \& Motor } \\
\text { Development } \\
\text { (Kalusugang Pisikal at Pagpapaunlad sa } \\
\text { Kakayahang Motor) }\end{array}$ & $\begin{array}{l}\text { Children are expected to develop both their } \\
\text { fine and gross motor skills to be able to } \\
\text { engage in wholesome physical and health } \\
\text { activities. }\end{array}$ \\
\hline $\begin{array}{l}\text { 3. Socio-Emotional Development } \\
\text { (Pagpapaunlad sa Kakayahang Sosyo } \\
\text { - Emosyunal) }\end{array}$ & $\begin{array}{l}\text { Children are expected to develop emotional } \\
\text { skills to relate well with others and } \\
\text { appreciate cultural diversity among the } \\
\text { school community and other people. }\end{array}$ \\
\hline $\begin{array}{l}\text { 4. Social Development (Pagpapaunlad } \\
\text { ng Kakayahang Makipamuhay) }\end{array}$ & $\begin{array}{l}\text { Children are expected to develop basic } \\
\text { concepts pertaining to her/himself and how } \\
\text { to relate well with other people in his/her } \\
\text { immediate environment and demonstrate } \\
\text { awareness of one's social identity. }\end{array}$ \\
\hline $\begin{array}{l}\text { 5. Language, Literacy } \\
\text { Communication }\end{array}$ & $\begin{array}{l}\text { This domain provides opportunities for self- } \\
\text { expression through language using the } \\
\text { mother tongue. Children are expected to } \\
\text { develop communicative skills in their first } \\
\text { language. }\end{array}$ \\
\hline
\end{tabular}




\begin{tabular}{|l|l|}
\hline 6. Mathematics & $\begin{array}{l}\text { Children are expected to understand and } \\
\text { demonstrate knowledge in identifying } \\
\text { numbers, as well as concepts of length, } \\
\text { capacity, mass, time and perform simple } \\
\text { operations using concrete objects. }\end{array}$ \\
\hline $\begin{array}{l}\text { 7. Understanding of the Physical and } \\
\text { Natural Environment }\end{array}$ & $\begin{array}{l}\text { Children are expected to demonstrate basic } \\
\text { understanding of concepts pertaining to } \\
\text { living and non-living things including } \\
\text { weather and uses these in categorizing things } \\
\text { in his/her environment. }\end{array}$ \\
\hline
\end{tabular}

The table reveals the 7 domains of learning in the kindergarten curriculum of the Philippines. It can be analyzed that the domains "Social Development" and "Socio-Emotional Development" can be regarded as one domain because the development of socio-emotional dimension of a child can lead to the development of the entire social dimension.

\section{Malaysian Setting}

The Preschool curriculum of Malaysia, that includes their Kindergarten Program, called "The National Pre-School Standard Curriculum (KSPK)" first implemented in 2010 has been revised to meet new policy demands under the 2013-2025 Malaysia Education Development Plan (PPPM) and current needs. This review is done to ensure that the quality of the curriculum implemented in preschools is in line with international standards.

The standardized curriculum translated in KSPK 2017 contains Content Standards, Learning Standards and Assessment Standards. This curriculum document is called the Curriculum and Assessment Standard Document (DSKP). The resulting DSKP has incorporated six spikes within the KSPK 2017 framework namely: 1) Communications Support; 2) Spirituality, Attitudes and Values; 3) Humanity; 4) Physical and Aesthetic Development; 5) Science and technology; and 6) Self-Skills.

Table 3. Learning Domains of Malaysian Preschool Standard Curriculum (KSPK)

\begin{tabular}{|c|l|}
\hline Domains of Learning & Descriptions \\
\hline 1. Communications Support & Communication support emphasizes oral \\
& and non-verbal speaking skills while \\
& interacting. This spine contains language \\
& discipline which must be studied by all pre- \\
& school students, namely: Malay and \\
& English. For students in Chinese / Tamil \\
\hline
\end{tabular}




\begin{tabular}{|c|c|}
\hline & $\begin{array}{l}\text { National Type Schools, they are required to } \\
\text { learn Chinese / Tamil. }\end{array}$ \\
\hline $\begin{array}{l}\text { 2. Spiritual Support, Attitude and } \\
\text { Value }\end{array}$ & $\begin{array}{l}\text { Spiritual Support, Attitude and Values give } \\
\text { priority to the aspect of appreciation of } \\
\text { religious practices, beliefs, attitudes and } \\
\text { values. This spine contains the discipline of } \\
\text { Islamic Education and Moral Education. } \\
\text { Islamic education is studied by Muslim } \\
\text { students, while Moral Education is studied } \\
\text { by non-Muslim students. }\end{array}$ \\
\hline 3. Humanity Support & $\begin{array}{l}\text { Humanitarian support emphasizes the } \\
\text { mastery of knowledge and practice of the } \\
\text { local, national and global community and } \\
\text { environment as well as the appreciation of } \\
\text { patriotism and unity. }\end{array}$ \\
\hline $\begin{array}{l}\text { 4. Support for Physical and Aesthetic } \\
\text { Development }\end{array}$ & $\begin{array}{l}\text { Support for Physical and Aesthetic } \\
\text { Development emphasizes physical and } \\
\text { health development for personal well-being } \\
\text { and the cultivation of imagination, } \\
\text { creativity, talent and appreciation of } \\
\text { artwork among students. This support } \\
\text { involves the physical and health care } \\
\text { component as well as creativity and } \\
\text { aesthetics }\end{array}$ \\
\hline 5. Spine of Science and Technology & $\begin{array}{l}\text { The support of Science and Technology } \\
\text { emphasizes scientific knowledge, skills and } \\
\text { scientific attitudes as well as math } \\
\text { knowledge and skills. The discipline } \\
\text { contained in this spine is Early Science and } \\
\text { Early Mathematics }\end{array}$ \\
\hline 6. Self Help Skills & $\begin{array}{l}\text { The Self Help Skills emphasize the } \\
\text { development of socio-emotions and the } \\
\text { development of interaction skills as well as } \\
\text { social skills amongst students. Leadership } \\
\text { and self-cultivation through curriculum and } \\
\text { co-curricular activities are also emphasized } \\
\text { in this sphere }\end{array}$ \\
\hline
\end{tabular}

The table presents the 6 domains of learning of the kindergarten curriculum of Malaysia. 
$\underline{\text { Point of Comparison of the Philippines and Malaysia Kindergarten Learning Domains }}$

Table 4. Comparison of Kindergarten Learning Domains of the Philippines and Malaysia

\begin{tabular}{|c|l|}
\hline Philippines & Malaysia \\
\hline $\begin{array}{l}\text { 1. Physical Health \& Motor } \\
\text { Development }\end{array}$ & $\begin{array}{l}\text { 1. Physical and Aesthetic } \\
\text { Development }\end{array}$ \\
\hline 2. Socio-Emotional Development & 2.Spirituality, Attitudes and Values \\
\hline 3. Values Education & 3.Humanity \\
\hline 4. Language, Literacy and & 4.Communications Support \\
\hline 5. Mathematics & 5.Science and technology \\
\hline 6. Social Development & 6.Self-help Skills \\
\hline 7. Understanding of the Physical \\
and Natural Environment
\end{tabular}

It can be gleaned in the table that the Philippine Kindergarten Curriculum Standard contains 7 learning domains, while Malaysia's Kurikulum Standard Prasekolah Kebangsaan (KSPK) or National Preschool Standard Curriculum has only 6.

However, it could be further explained that spirituality is one value that has been emphasized in the domains of learning of Malaysia because of their Religion. In contrast with the Philippines, Religion is not being studied solely as a domain but integrated in their "values education" domain.

In Malaysia's curriculum, Math does not stand as one major domain, instead it has been integrated in the domain, "Science and Technology". By this, it can be analyzed that Mathematics is one major subject that has been learned across levels of learning. Mathematics is a subject most-studied and explored and proven to be a large strand for students to study. It is then appropriate that Mathematics should stand as one big domain in the early childhood curriculum.

Moreover, it can also be extracted from the data that technology has been given emphasis by the Malaysia curriculum than the Philippine curriculum because it stands out as a big subject under "science and technology" domain.

Question Number 2. How does the curriculum framework affect the teaching and learning process?

The following are excerpts from the interview and FGD conducted with the respondents considering the themes that emerged from documentary analysis using NVivo. 
1. The government mandates the use of the national kindergarten curriculum

"In Malaysia, our curriculum is standard. It is suitable for children age 4-6. The domains of learning are in the curriculum. It depends on the teacher how to organize, build and manage activities. It's up to the teacher to make activities more fun with the children. The preschool follow the national curriculum." (R-7)

"We have a standard curriculum to follow, that's nationwide. Not only public but also private kindergartens use it. I find the curriculum structure good. ”(R-2)

\section{Kindergarten Education is Mother Tongue Based Instruction (MTB-MLE)}

"Mother tongue is very effective. You can just imagine, if the child's language at home is used in school, learning is so easy to achieve. We identify the dominant mother tongue in the school area so we can use it as the medium of instruction (MOI) in class. Like for instance, in Sto. Tomas, Sta. Maria and Cabagan areas, these are Ybanag speaking places, so we use Ybanag, the mother tongue, as the medium of instruction. It is very easy to understand by the children because they understand the language used." (R-4)

"Bahasa Malayu is the dominant and primary language I used in teaching. Most of our children are Malays. I have only 1 Chinese who speaks Tamil, and 1 Indian who speaks the Indian language. Parents send them to also learn Bahasa Malayu. Before, they are not good in speaking Bahasa Malayu, now they know already and they are fluent." (R-13)

"I want my child to speak Bahasa Malayu although we are Chinese. I can see the importance of this when my child play with her classmates and friends. She feel that she belongs to the group if she converse with them in Bahasa Malayu. They understand each other using the same language." $(R-22)$

"Yes. Visaya is the mother tongue. It's good and effective because the children understand the language. I use it when I teach the lesson. But I also use or translate the words in Filipino and English.”(R-11)

"Sometimes my pupils understand better English than Filipino language". (R-9)

I have difficulty thinking of other terms or vocabulary in the mother tongue. I can't find the exact words. So I shift to English or Filipino instead of Iloco." (R-12)

3. The Kindergarten curriculum is child-centered employing the integrative, thematic, collaborative, inquiry-based, reflective and constructive teaching adopting developmentally appropriate practices (DAP)

"Also I use project method. Children must have at least one project. At least one project in one year. Teacher can choose they want it what month. I do it at March to plant the flower. Another school they do different project. Project should be long like 1 to 2 months project. Sometimes, fish they bring fish and feed the fish. They do big building with a mineral water many bottles then build together a building. Long time for one month. That's project approach. At least one 
a year. The children work in group. 5 children in one group. So 5 groups for 25 children." ( $R$ 14)

"O yes! I do it by group. For example, a monggo plant. The children observe how the plant grows day by day with proper water and sunlight. We also do mixing of colours of red and yellow which results to orange something like that. In Science and Math, I asked the children to bring flour and food colour and they paste the formed object on illustration board. We do a lot of pasting in our Art work. We do bracelets out of macaroni bowls/pasta. They paint and do crayon candle in their art work. We cut letter $P$ as in papaya. We also do cooking. A group will prepare sandwich while another group prepares juice. One time, I brought a small oven. We baked pizzas and the children love putting ketchup on it. As simple as those activities but through these, the children explore and discover things for themselves." $(R-10)$

"Project approach is very effective for children because it initiated in the children. They can learn on their phases and level and they can learn what they want. It's more on child center. They question me "why do we have rain", "why the sky is not falling down", then we do the experiment on the cloud because of gravity. How the rain happen and then we show how condensation happens. So based on the question of children we discuss the content of the lesson. We just facilitate and lead them to the right answer. They ask, they investigate and they get the answer by them. That's project approach." (R-16)

"I employed thematic approach in teaching. One theme can be used to learn the different areas like Math, Arts, Science, and Reading. I am fond of grouping the children to do a particular task, then later connect it to other tasks in the different learning domains. I use a common theme for all of the tasks. I employ student-centered activity teaching. I want to do many things like structuring a corner for each subject in the classroom just like in the private schools. I want to put up a center corner in Science, Arts, Math, Reading and others. We just transferred from our old room. When I fix all, I will try to put up the corners."(R-11)

\section{Kindergarten Education is contextualized}

"The teachers are encouraged to devise materials in their dialects or mother tongue. As initial action, we came up with contextualized instructional materials already in Ybanag and it will follow in Echague for Yogad, and Palanan for Paranan. If the children read the story in their dialect, comprehension takes place." $(R-3)$

"We also plan to localize the language used in the progress report for parents to understand their children's performance and development in the program." (R-1)

"We have separate rooms. If your center has more than 3 special children, we need to have 1 teacher for them. Yes. 3 children with special needs need 1 sped teacher. We practice inclusive education but we pull out them for a special session and therapy." $(R-6)$

5. Kindergarten curriculum is play-based

"Play method is very effective. It is all in-one teaching. For example in playing a ball, they can see the shape and colour for math subject, and that's literacy, they can interact as they play 
for the socio-emotional aspect. In fieldtrips, for example, all domains are being developed. Say, you give 300Php to the child during fieldtrip, she will list those that she bought and that's Math, she will narrate her experiences, that's communication, sense of appreciation of the things she saw, for aesthetics, in a zoo, she can identify the animals, that's science... so many domains to develop already".(R-9)

\section{Parents involvement}

"My class can read and very good. I collaborate with class assistant and parents. We can organize. When we do activity, I handle a big group then give some to my assistant. Collaboration with parents what we learned in school at home." $(R-21)$

"Sometimes we have contribution. We have the aircond and fans repaired". (R-18)

"We participate in the school programs. My daughter joined the dance presentation on Buwan ng Nutrisyon. She's happy when I watch her." (R-20)

"We usually have the Brigada Eskwela before the classes start for the school year. Parents come and help in the school cleaning, they paint and plant." (R- 1)

"Right now I am pasting the assignment of all the children in their notebook. I am helping the teacher because she cannot do it all alone." (R-19)

"I am assigned today as the teacher aid. I clean the room after class and I help facilitate the distribution of worksheets of children during group activity. Parents rotate to serve as teacher aid." (R-17)

"Whenever a teacher is absent, she's sick, the assistant will take charge of the class." (R-5)

"We don't have teacher aid here. We do it all for the children. That's why it's very difficult." $(R-10)$

Question Number 3. What are the issues raised by the school heads, teachers and parents regarding the implementation of the national kindergarten curriculum in both countries?

\section{Issues in the implementation of the kindergarten program}

\section{Philippine Setting}

"For me, they should lessen the activities to 2-3 activities only because it is too difficult. Imagine, there are 5 activities in Work period 1, then another 5 in Work period 2. That's 10 activities in all for the whole duration of the session for only 3 hours. And what about the other sessions? How can I do all of these. I needed to move from one table to another to guide and explain to them the activity, with their big number. It is really so difficult. More so, the children are also confused. Before I used to follow it but I just ended up frustrated. I cannot attend to all of them. Now, I use worksheets to facilitate the activities. I download it from the net. I have to be flexible." (R-12)

"There is a need not only to integrate, but to really include as one domain "Peace Education" in the Kindergarten Curriculum. If children are taught the necessary values to attain peace, war will not happen as what we experience today in Marawi City between Maute group and the Government Military Force. Early teachings about peace should be done at an 
early stage so the children can live up to this value as they mature and become adults". We should draft a framework for Peace Education of the young children." (R-2)

"During my visit to the schools, I discovered that not all kinder rooms contain the furniture required by DepEd. Like for instance, the size of the room. Most of our rooms are not $7 \mathrm{~m} \times 9 \mathrm{~m}$ in area. Also the other requirements are not found like fire extinguishers, and emergency equipment and tools like whistle, etc. Also in some schools, their kindergarten building and rooms are located far from the gate. There is no playground equipped with facilities like swing, slides, etc. Although we have space for play but not sufficient. So there is more to provide in the kindergarten schools. It just requires budget from the government." $(R-4)$

"There are insufficient instructional materials and facilities. Not all children have their own materials. Others cannot afford to have it. The class size is big. I have 28 pupils compared to the standard number which is 25. When I taught in private, my pupils were only 15 and with teacher assistant." $(R-12)$

\section{Malaysian Setting}

"I want the teachers to teach effectively. They should make the teaching-learning process more fun and more interesting. They have difficulty on this aspect. They need more training to improve their skills in teaching." $(R-8)$

"I am not quite satisfied with the teacher's competence. I wish they are more pro-active. The personality of the Malay teachers has something to do with their ability to teach." $(R-24)$

"I want my child to learn how to read, how to count and write." I don't want too much play and play without learning." (R-23)

"The teachers are not fluent speakers of English." I want my child to learn from her how to speak English.” (R-21)

"The challenge is, how to make the community, the parents to follow the school rules. They still send their children to school late. I want them to manage their time. They must come early. I just oral say it to them maybe after this I will give the memo." (R-5)

\section{DISCUSSION}

The data presentation above revealed the similarities and differences between the kindergarten programs of the Philippines and Malaysia on their respective curriculum framework. The Philippine Kindergarten Curriculum Standard contains 7 learning domains, while Malaysia's Kurikulum Standard Prasekolah Kebangsaan (KSPK) or National Preschool Standard Curriculum has only 6 learning domains.

However, it could be further explained that spirituality is one value that has been emphasized in the domains of learning of Malaysia because of their Religion. In contrast with the Philippines, Religion is not being studied solely as a domain but integrated in their "values education" domain. 
In Malaysia's curriculum, Mathematics does not stand as one major domain, instead it has been integrated in the domain, "Science and Technology". By this, it can be analyzed that Mathematics is one major subject that has been learned across levels of learning. Mathematics is a subject most-studied and explored and proven to be a large strand for students to study. It is then appropriate that Mathematics should stand as one big domain in the early childhood curriculum.

Moreover, it can also be extracted from the data that technology has been given emphasis by the Malaysia curriculum than the Philippine curriculum because it stands out as a big subject under "science and technology" domain. Hence, there is a need for curriculum review considering the findings of this study.

The findings also demonstrate the points of comparison and contrast on the teachinglearning process reflected in the curriculum of Malaysia and the Philippines considering the following themes as follows: 1) The government mandates the use of National kindergarten curriculum; 2) Kindergarten education is Mother-tongued instruction based; 3) The Kindergarten curriculum is child centered employing the integrative, thematic, collaborative, inquiry-based, reflective and constructive teaching; 4) Kindergarten education is contextualized; 5) Kindergarten curriculum is play-based; and 6) Kindergarten curriculum involves parents participation for successful development of the children.

Based on these themes, the following have been found out to be the similarities between the kindergarten curricula of Malaysia and the Philippines: 1) Both countries have a standard national kindergarten curriculum being followed by both public and private kindergarten schools. 2) Both countries recognize the role played by Mother tongue to be effective language for successful learning; 3) Teachers adopt the developmentally appropriate practices in teaching 4) Both use contextualization when they teach 5) Both countries strongly adhere to play-based instruction; 6) Parents show their support to the kindergarten program of the school.

The points of difference in the teaching-learning process reflected in the curriculum of the two countries are as follows: 1) Kindergarten is mandatory for children aged 5 and is included in the Basic Education in the Philippines while in Malaysia, Kindergarten is not mandatory to entrance to Standard 1;2) The age of kinder in the Philippines is 5 years old while in Malaysia, kinder is 6 years old; 3) Malaysia's kinder class consists of 1 teacher and 1 teacher-aid while Philippine's kinder class consists only of 1 teacher with no teacher-aid; and 4) Schools in Malaysia have Special Education classes for the primary level and preschool level respectively while in the Philippines, not all schools have SPED classes.

The interview data also reveal the issues prevalent in the kindergarten program implementation of Malaysia. They are as follows: 1) dissatisfaction of parents in the teaching competence of the teachers; 2) lack of trainings for teachers; 3) too much use of play or the wrong use of play as an approach for learning; 4) Teachers' inadequacy to speak English; 5) Parents inability to send their children to school early or on time. 
Finally, the issues facing the kindergarten curriculum program of the Philippines include the following: 1) Too much activities included in the Curriculum Guide; 2) Lack of Peace Education component in the curriculum framework; 3) Most of the kinder schools are non-compliance of the standards indicated in the Omnibus Policy like size of rooms, location of the kinder building, class size, and supposed to be furniture found in the room; and 4) Insufficient instructional materials and facilities like playground.

\section{CONCLUSION}

Philippines and Malaysia have points of similarities and differences in their learning domains and on teaching and learning processes being implemented by the teachers with the children. The issues raised can be a point of reflection to refine and enhance more the curriculum in both countries. The findings of the study call for the collaboration of policy makers and practitioners as well as all stakeholders to address the issues in the kindergarten program revealed by the study. Revision of the curriculum needs to be done considering its most valued core-the children. The study has several limitations and is calling for more future studies to deal with deeper analysis of kindergarten curriculum and other program components for quality delivery of the program in Malaysia and in the Philippines.

\section{REFERENCES}

Abu Taleb, T.F. (2013). "NAEYC's Key Attributes of Quality Preschool Programs" Applied to the Jordanian Kindergarten Context. Early Childhood Education Journal, 41: 307. doi:10.1007/s10643-012-0550-9

CDC (2007). Early Childhood Care and Education Policy Implementation Review 2007.Curriculum Development Centre, Ministry of Education Malaysia.

DepEd Order 32 s. 2012 "Implementing Rules and Regulation of the Republic Act 10157"

Education Act 1996 (Act 550)

Fees, B.S., Hoover, L., \& Zheng, F. (2014). Chinese Kindergarten Teachers' Perceived Changes in Their Teaching Philosophies and Practices: A Case Study in a University-Affiliated Program .IJEC .46: 231. doi:10.1007/s13158-014-0109-6)

Haug, K.H. \& Storø, J. ICEP .(2013). Kindergarten — a Universal Right for Children in Norway7: 1. doi:10.1007/2288-6729-7-2-1. International Journal of Child Care and Education Policy,7(2), 1-13.

Preliminary Report Malaysia Development Plan (2013-2025), 2012. Ministry of Education Malaysia.

Republic Act No. 10157 "The Kindergarten Education Act"

Republic Act No. 10533- "Enhanced Basic Education Act of 2013"

SEAMEO INNOTECH. (2012). K to 12 in Southeast Asia: Regional Comparison of the Structure, Content, Organization and Adequacy of Basic Education. Quezon City: Philippines. 